International Journal of Biology, Pharmacy and Allied Sciences (IJBPAS) 'A Bridge Botusen caboratory and QRendo'

Www.jibpas.com

\title{
KSHARA KARMA IN THE MANAGEMENT OF DUSHTAVRANA (CHRONIC NON-HEALING WOUND) - A CASE REPORT
}

\section{ASMA $^{* 1}$, DAVE O $^{2}$ AND TOSHIKHANE HD $^{3}$}

1: PhD Scholar, Dept. of PhD studies in Shalya Tantra, Parul Institute of Ayurveda, Parul

University, Vadodara, Gujarat, India

2: Professor, Dept. of PhD studies in Shalya Tantra, Parul Institute of Ayurveda, Parul

University, Vadodara, Gujarat, India

3: Dean, Faculty of Ayurveda, Dept. of PhD studies in Shalya Tantra, Parul Institute of

Ayurveda, Parul University, Vadodara, Gujarat

*Corresponding Author: Dr. Asma: E Mail: dr.asma.hz@gmail.com

Received 12 ${ }^{\text {th }}$ Dec. 2021; Revised $14^{\text {th }}$ Jan. 2022; Accepted $7^{\text {th }}$ Feb. 2022; Available online $5^{\text {th }}$ March 2022

\section{https://doi.org/10.31032/IJBPAS/2022/11.3.1087}

\section{ABSTRACT}

Introduction - A chronic wound is one that does not heal in a predictable sequence of stages. Ayurveda has given a unique treatment modality i.e., para-surgical procedures and Kshara karma is one among them and it serves the purpose of Vrana Shodhana (Wound debridement/cleansing).

Case Report - A 62-year-old male complaints of non-healing wound on the left lower leg for 2 months with history of blunt trauma, received symptomatic treatment from local doctor and got quite relief but no history of taking rest or regular dressings which aggravated the symptoms, on examination revealed ulcer $7 \times 4 \mathrm{~cm}$ in size on Antero-medial aspect of the left lower leg and $2 \times 1 \mathrm{~cm}$ at dorsum of left foot. Chronic wound management is still a difficult task and even Acharya Sushruta broadly explained the concept of Kshara and also indicated for the treatment of Dushtavrana (Chronic wound). In this case will review wound healing physiology in 3 stages and discuss the current approach for treating a wound.

Diagnosis - Case was diagnosed as Chronic wound as per contemporary science and Dushtavrana as per Ayurveda. 
Intervention - The case was managed by Kshara karma as an external application and post operative Yashtimadhu (Glycyrrhiza glabra) and Ghrita (Cow ghee) was applied for wound dressing. Kaishora Guggulu and Manjishtadi Kashaya administered internally.

Outcome - The wound took 3 months for complete healing with improvement in the patient quality of life to perform his routine activities.

Conclusion - The adopted Ayurveda treatment i.e., Kshara karma has given promising results in the management of Dushtavrana (Chronic wound).

\section{Keywords: Ayurveda, Dushtavrana, Kshara karma, Palasha Pratisaaraneeya Kshara, Vrana}

\section{Shodhana, Vrana Ropana, Shashtiupakrama, Chronic Wound, Wound Healing}

\section{INTRODUCTION}

\section{Acharya Sushruta describes Vrana}

(Wound) as Destruction or discontinuity of the body tissue. When Vrana (Wound) fails to heal within time or which is difficult to heal, the dosha invades and does the dushana and hence called as Dushtavrana (Chronic Wound). Dushtavrana (Chronic Wound) is the one in which there is localization of three Doshas, which has a bad odour, has abnormal colour, with profuse discharge, intense pain and takes a long period to heal. ${ }^{1}$ A Chronic wound, on the other hand, is the wound that is persistent and doesn't heal in a regular sequence of stages within a predictable time frame. They are typically prone to suppuration by microorganisms and remain in the inflammatory stage for an extended period of time. $^{2}$

In India, a study estimated a prevalence rate of chronic wounds in the community as 4.5 per 1000 population where as that of acute wounds was nearly doubled at 10.5 per1000 population.
Many chronic wounds, particularly in rural regions, do not heal due to insufficient wound care, i.e., exposure to infection and prolonging of the inflammatory phase play a major role in delaying the healing process, resulting in the wound being covered with slough/necrotic tissue and purulent discharge. he ultimate goal of any surgeon is to remove all necrotic tissue and wound exudates for the purpose of wound closure or to facilitate the wound healing process by generating favorable conditions that allow the wound to heal properly. Management of Chronic wound includes debridement, irrigation and wound cleansing, debridement is often painful and the entire necrotic tissue cannot be removed at once and wound cleansing agents have been shown to prolong wound healing. ${ }^{4}$

$$
\text { Sushruta has described }
$$
Shashtiupakramas (60 measures) for the comprehensive management of Vrana (Wound), which includes local as well as the systematic use of different drugs and 
treatment modalities under a dedicated chapter. Dushtavrana (Chronic wound) is a long-standing ulcer where removing debris enabling drug to reach healthy tissue is more important. 5 Kshara karma (application of Pratisaraneeya Teekshna kshara) is a para-surgical procedure of Ayurveda indicated for the management of Dushtavrana (Chronic wound). A medicine (alkaline in nature) derived from a combination of various herbs is applied over the Chronic wound which serves the purpose of Vrana Shodhana (Wound cleansing). The superiority of kshara over shastras (sharp instruments) and anushastras (accessory sharp instruments) has been mentioned in Sushruta Samhita. ${ }^{6}$

Here, we are reporting a case which was treated with the application of Palasha Teekshna Pratisaaraneeya Kshara and it has a given promising result.

\section{CASE REPORT}

A 62-year-old male non-diabetic, non-hypertensive patient visited our hospital with the complaint of non-healing wound on the left lower leg in the past 2 months associated with mild purulent discharge. Patient was a chronic smoker, smokes 20 bd's per day for last 20 years and consumed alcohol occasionally and he was a labour. The case was treated at SVM Ayurvedic Medical College and RPK
Ayurvedic Hospital, Ilkal, Karnataka, (OPD No. 2003597 and IPD No. 2000424).

Regarding aetiology there was a history of blunt trauma, since then he developed an ulcer over the left lower leg. Patient had consulted a local doctor and received symptomatic treatment and got quite relief from the symptoms but there was no history of taking rest, immobilization or regular dressings which aggravated the symptoms like the wound increased in size for 1 month and is constant since then. Past history and family history were not contributory.

\section{Clinical Findings}

General examination revealed that the patient was averagely built and vitals were normal. Systemic examination i.e., Central Nervous System, Cardiovascular System and Respiratory System showed normal findings. Local examination showed a large ulcer, $7 \times 4 \mathrm{~cm}$ in size, situated on Antero-medial aspect of the left lower leg and a small ulcer $2 \times 1 \mathrm{~cm}$ in size at dorsum of left foot (Fig.1). It had well defined, regular white margin with absence of blue line of growing epithelium and a sloping edge all along the circumference. Floor showed seropurulent discharge, slough and was covered by pale, flat granulation tissue. Surrounding skin showed hyperpigmentation, mild oedema, no redness, dilated veins, scars or cyanosis. 
Surrounding skin showed mild pitting oedema, no local rise of temperature, tenderness or induration. The edge was firm, non-tender. Granulation tissue was non-tender and did not bleed on touch. There was no enlargement of lymph nodes on both the sides. The pulsations of the dorsalis pedis, posterior tibial, popliteal and femoral arteries on both sides were well felt and equal and the movement of the ankle joint was also normal.

\section{Timeline}

In September 2019 patient had a history of blunt trauma, since then he developed a wound over the left lower leg. Patient had consulted a local doctor and received symptomatic treatment and got quite relief from the symptoms but there was no history of taking rest, immobilization or regular dressings which aggravated the symptoms like the wound increased in size for 1 month and is constant since then. In February 2020, patient visited SVM Ayurvedic Medical College and RPK Ayurvedic Hospital, Ilkal, Karnataka where it was treated with external application and internal medications.

\section{Diagnostic Assessment}

Blood investigation showed $\mathrm{Hb} \%$ 11.6gm\%; TLC - 4,300 cells/cum; ESR $22 \mathrm{~mm}$ at $1^{\text {st }}$ hour; RBS - $95 \mathrm{mg} / \mathrm{dl}$; PCV 40.2; Platelet - 3.02 lakh/microlitre; RBC -
$4.98 \mathrm{million} / \mathrm{cu} \mathrm{mm}$. Chest X-ray was normal.

\section{Therapeutic Intervention}

Kshara karma has broadly explained by Acharya Sushruta and is widely used as a para-surgical procedure for the management of various disorders. ${ }^{7}$ Kshara Karma is one such procedure explained under the heading of Shashtiupakrama (60 procedures) which was used as an external application for Vrana Shodhana (Wound Cleansing) ${ }^{8}$ and as a post operative procedure Yashtimadhu (Glycyrrhiza glabra) and Ghrita (Cow ghee) was applied as wound dressing for Vrana Ropana (Wound Healing). 9 Kaishora Guggulu ${ }^{10}$ and Manjishtadi Kashaya ${ }^{11}$ was advised for internal administration as these cleanses the wound and promotes healing (Table 1).

\section{Preparation of Palasha Pratisaaraneeya} Kshara $^{12}$

Palasha panchanga (5 useful parts of Butea monosperma) properly dried approx. $10 \mathrm{~kg}$, spread on even land, cut into small pieces and heaped together with Sudha (lime stones), it was then ignited and burnt into ash and was collected separately $(1 \mathrm{~kg})$. Obtained ash was dissolved in 6 parts of water and left undisturbed overnight. Next day the supernatant fluid was taken in a separate vessel and the residue was discarded. Supernatant fluid 
was then filtered 21 times through a four folded cotton cloth and the obtained filtrate was treated on mild fire while slowly stirring by a ladle. When it was clear, red, sharp and slimy, it was re-filtered and the filtrate was again placed on fire after removing the separated residue. Some amount of ksharajala (boiling filtrate) taken out of the same filtrate and was kept apart. Thereafter Sudha (pebbles of lime stone), Shankha (Conch shell), Shukti (Oyster shell) and Kapardika (Cowrie shell) (Table 2) was made red hot, dipped in ksharajala (filtrate which was kept apart in an iron vessel) and was made into a paste (100 gm). This prepared paste was then mixed with the boiling filtrate placed on fire while constantly stirring by a ladle. Later, fine powder of Chitraka (Plumbago zeylanica), Langali (Gloriosa superba), Hingu (Ferulanarthex), Vacha (Acorus calamus) and Ativisha (Aconitum heterophyllum) (Table 2) in equal proportions was added to the same boiling filtrate placed on fire and stirred keeping constant vigilance. When it was boiled appropriately i.e., neither too thick nor too thin, it was taken out of the furnace and collected Palasha Pratisaaraneeya Kshara stored in an air tight container.

\section{Procedure of application of Palasha} Pratisaaraneeya Kshara

Wound and its surrounding area was cleaned with Normal saline. Palasha Pratisaaraneeya Kshara was applied to the wound bed covered with slough and necrotic tissue and left up to 100 matra kala (approx. $60 \mathrm{sec}$ ). Later, Kshara was removed and Nimbu swarasa (Lemon juice) was applied to nullify the action of Kshara, followed by application of Yastimadhu (Glycyrrhiza glabra) and Ghrita (Cow ghee) for wound dressing. Kshara karma was done on every $3^{\text {rd }}$ day for 10 days (4 sittings), followed by daily dressing with application of Yashtimadhu (Glycyrrhiza glabra) and Ghrita (Cow ghee).

\section{Follow up and Outcome}

Wound was assessed on every $3^{\text {rd }}$ day by Bates Jensen Wound Assessment Tool and advised to provide rest to the affected leg. The wound healed after 3 months (Fig.2) with normal scar formation. Patient can walk without any difficulty and able to perform his routine activities. Follow up of patient was done for 1 year; there was no recurrence of wound. Blood investigations were performed after 3 months which were found within normal limits. 
Table 1: Therapeutic Intervention and Oral Medications

\begin{tabular}{|c|c|c|c|c|c|c|c|c|c|c|}
\hline \multirow[t]{2}{*}{ Plan of Care } & \multirow[t]{2}{*}{ Procedure } & \multicolumn{9}{|c|}{ Duration (Days) } \\
\hline & & $\begin{array}{l}1- \\
3\end{array}$ & $\begin{array}{c}4- \\
6\end{array}$ & $\begin{array}{l}7- \\
9\end{array}$ & $\begin{array}{c}10- \\
12\end{array}$ & $\begin{array}{l}13- \\
15\end{array}$ & $\begin{array}{l}16- \\
30\end{array}$ & $\begin{array}{c}31- \\
40\end{array}$ & $\begin{array}{l}41- \\
52\end{array}$ & $\begin{array}{c}53- \\
60\end{array}$ \\
\hline Vrana Shodhana & Kshara karma & $\checkmark$ & $\checkmark$ & $\checkmark$ & $\checkmark$ & & & & & \\
\hline Vrana Ropana & Yashtimadhu and Ghrita & $\checkmark$ & $\checkmark$ & $\checkmark$ & $\checkmark$ & $\checkmark$ & $\checkmark$ & $\checkmark$ & $\checkmark$ & $\checkmark$ \\
\hline Kaishora Guggulu & $\begin{array}{c}250 m g 2 \text { tab twice daily } \\
\text { after food }\end{array}$ & $\checkmark$ & $\checkmark$ & $\checkmark$ & $\checkmark$ & $\checkmark$ & $\checkmark$ & $\checkmark$ & $\checkmark$ & $\checkmark$ \\
\hline Manjishtadi Kashaya & $\begin{array}{c}20 m l \text { thrice daily before } \\
\text { food with equal quantity of } \\
\text { water }\end{array}$ & $\checkmark$ & $\checkmark$ & $\checkmark$ & $\checkmark$ & $\checkmark$ & $\checkmark$ & $\checkmark$ & $\checkmark$ & $\checkmark$ \\
\hline
\end{tabular}

Table 2: Preparation of Palasha Pratisaaraneeya Kshara

\begin{tabular}{|c|c|c|}
\hline S. No. & Drugs Used & Latin Name \\
\hline 1. & Palasha & Butea monosperma \\
\hline 2. & Sudha & Conch shell \\
\hline 3. & Shankha & Oyster shell \\
\hline 4. & Shukti & Cowrie shell \\
\hline 5. & Kapardika & Plumbago zeylanica \\
\hline 6. & Chitraka & Gloriosa superba \\
\hline 7. & Hingali & Ferula narthex \\
\hline 8. & Vacha & Acorus calamus \\
\hline 9. & Ativisha & Aconitum heterophyllum \\
\hline 10. & &
\end{tabular}

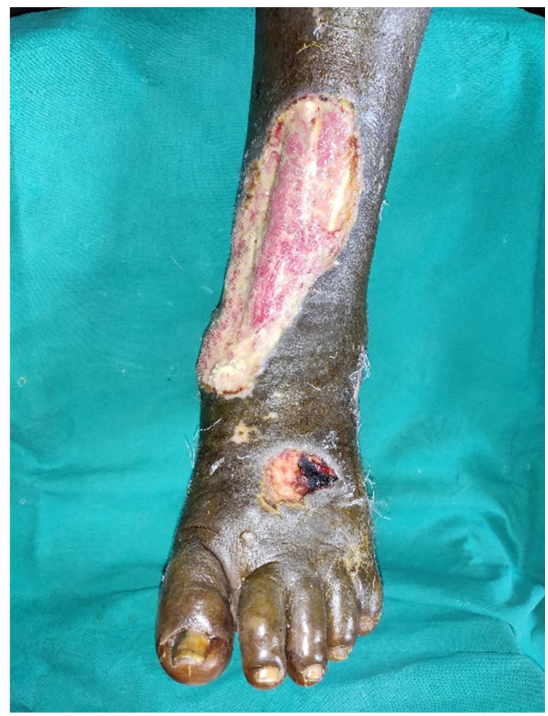

Fig. 1: Before Treatment

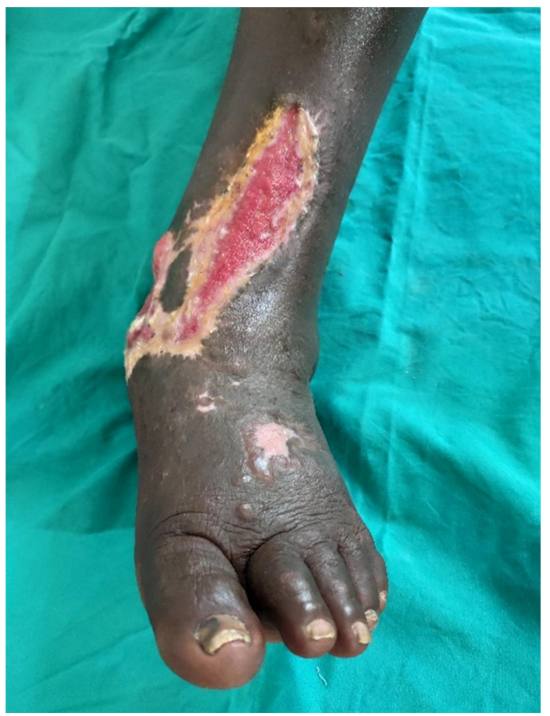

Fig.2: After Treatment

\section{DISCUSSION}

Local treatment: can be understood in 3 stages of healing of an Ulcer:

1. Stage of separation of slough

2. Stage of formation of granulation tissue.

3. Stage of epithelialization

\section{Stage of separation of slough:}

Debridement or the removal of non-viable tissue material, is a crucial concept in wound care. This can be accomplished through surgical or autolytic/enzymatic mechanisms; in either case, the goal is to expose healthy, well-perfused tissue that can proliferate and populate the wound bed 
via epithelial cell migration, rather than retaining necrotic debris that serves as fuel for infection and hinders wound healing. ${ }^{13}$ Kshara with its unique properties acts as an instrumentation to achieve the basic treatment principle of Wound management i.e., debridement or cleansing by dissolving and removing slough/necrotic tissue efficiently. ${ }^{14}$ As being hygroscopic reduces an oedema of the granulation tissue. Once the slough is removed further application of Kshara should not be entertained, as the Kshara burns the healthy tissue and hampers with granulation tissue formation.

\section{Stage of formation of granulation} tissue:

A moist occlusive dressing supports the inflammatory phase by generating an environment with low oxygen tension (thereby activating such factors as hypoxiainducible factor-1) and also promotes and speed up the process of reepithelialization $^{15}$.

Yashtimadhu (Glycyrrhiza glabra) and Ghrita (Cow ghee) was applied till the granulation tissue almost reached the surface. Ghrita (Cow ghee) lubricates and prevents the sticking of the dressings to the granulations by maintaining moisture in the dressing. As it is loaded with vitamins and antioxidants, nourishment is imperative at this stage. Yashtimadhu (Glycyrrhiza glabra) stimulate the formulation of granulation tissue.

3. Stage of epithelialization: If an ulcer is more than $4-5 \mathrm{cms}$ in size, complete epithelialization may not occur without significance fibrosis and contracture. Hence, an aim was to initiate quick healing by increasing the rate of re-epithelialization with minimum fibrosis and better cosmetic as well as functional result.

\section{CONCLUSION}

Although the optimal time and frequency for Kshara karma remain unclear, since it is likely to vary widely depending on the type of wound being treated, but there is widespread agreement that it is an important part of wound management to facilitate the wound healing process by generating favorable conditions that allow the wound to heal properly. Kshara with its special qualities work as an instrument to achieve the basic treatment principle of wound management, i.e., debridement or cleansing, by effectively dissolving and eliminating slough/necrotic tissue. The present case was successfully managed by various Kshara karma along with internal medications and has given promising result.

\section{REFERENCES}

[1] Ajmeer AS, Dudhamal TS, Gupta SK, Mahanta V. Topical application of Katupila (Securinega leucopyrus) in Dushta Vrana (chronic wound) 
showing excellent healing effect: A case study. Ayu. 2014 Apr;35(2):175-8. doi: 10.4103/0974-8520.146238. PMID: 25558163 ; PMCID: PMC4279324.

[2] Balasooriya D, Karunarathna C, Uluwaduge I. Wound healing potential of bark paste of Pongamia pinnata along with hirudotherapy: A case report. J Ayurveda Integr Med. 2021 Apr-Jun;12(2):384-388. doi: 10.1016/j.jaim.2021.01.014. Epub 2021 Apr 2. PMID: 33814265; PMCID: PMC8185996.

[3] Shukla VK, Ansari MA, Gupta SK. Wound healing research: a perspective from India. Int $\mathrm{J}$ Low Extrem Wounds. 2005 Mar;4(1):78. doi: 10.1177/1534734604273660. PMID: 15860447.

[4] Baria J, Gupta SK, Bhuyan C. Clinical study of Manjishthadi Ghrita in vrana ropana. Ayu. 2011 Jan;32(1):95-9. doi: 10.4103/09748520.85738. PMID: 22131765; PMCID: PMC3215426.

[5] Ajmeer AS, Dudhamal TS, Gupta SK, Mahanta V. Topical application of Katupila (Securinega leucopyrus) in Dushta Vrana (chronic wound) showing excellent healing effect: A case study. Ayu. 2014 Apr;35(2):175-8. doi:
10.4103/0974-8520.146238. PMID: 25558163; PMCID: PMC4279324.

[6] Mahapatra A, Srinivasan A, Sujithra R, Bhat RP. Management of internal hemorrhoids by Kshara karma: An educational case report. J Ayurveda Integr Med. 2012 Jul;3(3):115-8. doi: 10.4103/09759476.100169. PMID: 23125506; PMCID: PMC3487235.

[7] Mahapatra A, Srinivasan A, Sujithra R, Bhat RP. Management of internal hemorrhoids by Kshara karma: An educational case report. Journal of Ayurveda and Integrative Medicine. 2012 Jul;3(3):115-118. DOI: $\quad 10.4103 / 0975-9476.100169$. PMID: 23125506; PMCID: PMC3487235.

[8] Dudhamal TS, Gupta SK, Bhuyan C. Role of honey (Madhu) in the management of wounds (Dushta Vrana). Int J Ayurveda Res. 2010 Oct;1(4):271-3. doi: 10.4103/09747788.76793. PMID: 21455457; PMCID: PMC3059452.

[9] Patel JR, Dudhamal TS. A comparative clinical study of Yashtimadhu Ghrita and lignocaine-nifedipine ointment in the management of Parikartika (acute fissure-inano). Ayu. 2017 Jan-Jun;38(1- 
2):46-51.

doi:

10.4103/ayu.AYU_93_17. PMID:

29861592 ; PMCID: PMC5954261.

[10] Bharati PL, Agrawal P, Prakash O.

A case study on the management

of dry gangrene by Kaishore

Guggulu, Sanjivani

Vati and Dashanga Lepa. Ayu.

2019 Jan-Mar;40(1):48-52. doi:

10.4103/ayu.AYU_244_18.

PMID: 31831969 ; PMCID:

PMC6891997.

[11] Jadav HR, Ghetiya H, Prashanth

B, et al. Ayurvedic management of adverse drug reactions with

Shvitrahara Varti. Ayu. 2013

Apr;34(2):189-192. DOI:

10.4103/0974-8520.119676.

PMID: 24250129; PMCID:

PMC3821249.

[12] Mahapatra A, Srinivasan A, Sujithra R, Bhat RP. Management of internal hemorrhoids by Kshara karma: An educational case report. J Ayurveda Integr Med. 2012 Jul;3(3):115-8. doi: 10.4103/0975-
9476.100169. PMID: 23125506;

PMCID: PMC3487235.

[13] Han G, Ceilley R. Chronic Wound Healing: A Review of Current Management and Treatments. Adv Ther. 2017 Mar;34(3):599-610. doi: 10.1007/s12325-017-0478-y. Epub 2017 Jan 21. PMID: 28108895;

PMCID:

PMC5350204.

[14] Kotrannavar VK, Angadi SS. Kshara application for turbinate hypertrophy. J Ayurveda Integr Med. 2013 Oct;4(4):241-4. doi: 10.4103/0975-9476.123722.

PMID: 24459392; PMCID: PMC3891181.

[15] Han G, Ceilley R. Chronic Wound Healing: A Review of Current Management and Treatments. Adv Ther. 2017 Mar;34(3):599-610. doi: 10.1007/s12325-017-0478-y. Epub 2017 Jan 21. PMID: 28108895; PMCID: PMC5350204. 